\title{
DESIGN OF AN 8-SPEED INTERNAL GEAR HUB WITH A ROTARY CONTROL MECHANISM FOR BICYCLES
}

\author{
Yi-Chang $\mathrm{Wu}, \mathrm{Li}$-An Chen
}

Original scientific paper

This paper proposes a novel design of an 8-speed internal gear hub which consists of a distributed-flow-type planetary gear mechanism and a rotary gearshifting control mechanism. The distributed-flow-type planetary gear mechanism comprises two transmission units and one differential unit to provide eight forward gears. A clutching sequence table and a set of feasible solutions for the number of gear-teeth of the planetary gear mechanism are synthesized. The power transmission path at each gear stage is checked to verify the validity of the planetary gear mechanism. The main components of a rotary gear-shifting control mechanism to cooperate with the gear mechanism and mechanically control the engagement or disengagement of each locking clutch are illustrated. Based on the clutching sequence table, the design of a rotary gear-shifting control mechanism is presented, and the unique features of the proposed design are addressed. Finally, a compact 8-speed internal gear hub for bicycles is presented.

Keywords: internal gear hub; planetary gear mechanism; rotary control mechanism

Konstrukcija 8-brzinskog prijenosnika s unutarnjim ozubljenjem i rotacijskim upravljačkim mehanizmom za bicikle

Izvorni znanstveni članak U radu se predlaže nova konstrukcija 8-brzinskog prijenosnika s unutarnjim ozubljenjem koji se sastoji od planetarnog prijenosnog mehanizma protočnog tipa i rotacijskog upravljačkog mehanizma za mijenjanje brzina. Planetarni prijenosni mehanizam se sastoji od dva prijenosna uređaja i jednog diferencijalnog prijenosnika za osam prednjih zupčanika. Sintetizirani su tabela slijeda kvačenja i niz mogućih rješenja za broj zubi zupčanika planetarnog prijenosnog uređaja. Kontrolira se slijed prijenosa snage kod svake promjene stupnja prijenosa zbog provjere ispravnosti planetarnog prijenosnog mehanizma. Prikazane su glavne komponente rotacijskog upravljačkog mehanizma za mijenjanje brzina usklađene s prijenosnim mehanizmom i mehaničkim upravljanjem zahvaćanja ili iskopćavanja svakog zabravljenja spojke. Na temelju tabele slijeda kvaćenja, predstavljena je konstrukcija rotacijskog upravljačkog mehanizma za mijenjanje brzina i posebne karakteristike te konstrukcije. Konačno, predstavljena je kompaktni 8-brzinskog prijenosnik s unutrašnjim ozubljenjem.

Ključne riječi: prijenosnika s unutrašnjim ozubljenjem; planetarni prijenosni uređaj; rotacijski upravljački mehanizam

\section{Introduction}

With ever increasing fossil energy pollution concerns, bicycling is becoming an even more popular way for energy conservation and emissions reductions. Whether the bicycle is used for recreation, urban transportation or competitive sport, a multi-speed transmission mechanism is an important mechanical device that is frequently equipped for changing the rotational speed of the rear wheel of a bicycle. So far, there are two different types of multi-speed transmission systems commonly used in bicycles: the derailleur system and the internal gear hub system. A derailleur system consists of a chain, multiple sprockets and a chain-guide mechanism to move the chain from one sprocket to another. The multiple sprockets in this system are exposed outside, whereas the transmission and gear-shifting control mechanisms of an internal gear hub are completely protected from external impact, water, road salt and grit due to the protection of the hub shell. With no outside contaminants to muck up the control mechanism, an internal gear hub can be counted on to shift smoothly from one gear to the next. The internal gear hub generally requires less maintenance and is considered more reliable than the comparable external derailleur. Moreover, a special feature of the internal gear hub is that it can shift at a stop, which is an advantage in stop-and-go urban traffic. For these reasons, internal gear hubs are becoming increasingly popular.

An internal gear hub in a bicycle is a multi-speed transmission device, which consists of a gear mechanism and a gear-shifting control mechanism, connected with a rear sprocket installed on the rear wheel. In 1974, Schulz and Schwerdhofer [1] proposed a three-speed internal gear hub comprised of a 5-link, two-degrees of freedom (2-DOF) basic planetary gear train as the transmission mechanism, and an axially speed-changing control mechanism to govern the power transmission paths and the corresponding gear ratios. In 1975, Hillyer [2] presented an 8-link, 3-DOF planetary gear train, which comprised two sets of basic planetary gear trains with a common planet cage, as the transmission mechanism. An axially adjustable control mechanism was further used to control pawl-and-ratchet clutches so as to provide five forward gears. From then on, bicycle companies, including Fichtel \& Sachs AG, Shimano, Sun Race Sturmey Archer and Raleigh, have successfully developed their own internal gear hubs $[3 \div 6]$. Most of these products, however, provided less than eight forward gears, until in 1996, Fichtel \& Sachs AG Company announced a novel 12-speed internal gear hub [7]. The main body of this internal gear hub was a distributed-flow-type planetary gear mechanism which consisted of two sets of compound planetary gear trains and one differential planetary gear set. The input power from the rear sprocket split into two sets of compound planetary gear trains and then converged on the differential planetary gear set to transmit the output power to the hub shell. This design strategy was a breakthrough in providing more forward gears and a wider range of total gear ratio than existing designs for the internal gear hubs of bicycles. In 2008, Hsu and Wen [8] proposed a 16-speed, distributed-flowtype internal gear hub that consisted of three sets of compound planetary gear trains and one differential planetary gear set. In 2012, Wu and Ren [9] applied a 
distributed-flow-type planetary gear mechanism with four sets of basic planetary gear trains and one differential planetary gear set to provide 16 forward gears. However, neither study considered the embodiment design of the control mechanisms responsible for gear shifting. Feasible designs of control mechanisms which integrate with the distributed-flow-type planetary gear mechanisms to form a compact multi-speed internal gear hub still needed to be developed.

The purpose of this study was to present a novel 8speed internal gear hub for bicycles that integrated a distributed-flow-type planetary gear mechanism with a rotary gear-shifting control mechanism. In Section 2, a 13-link, 4-DOF distributed-flow-type planetary gear mechanism is introduced. A kinematic analysis of the planetary gear mechanism is performed using the fundamental circuit method. A clutching sequence table and the synthesis of gear-teeth numbers are presented to provide eight forward gears. Section 3 introduces mechanical components of a rotary gear-shifting control mechanism and the embodiment design of a rotary gearshifting control mechanism is also illustrated. A novel 8speed internal gear hub for bicycles and its unique features are presented in Section 4. The conclusion is offered in Section 5.

\section{A distributed-flow-type planetary gear mechanism}

A multi-speed internal gear hub for bicycles usually employs a planetary gear train to achieve a set of speed ratios. This is because planetary gear trains have the principal advantages of a large reduction ratio, compactness, high efficiency and the capability of differential drive $[10,11]$. Planetary gear trains used in internal gear hubs are called planetary gear mechanisms. In order to provide enough forward gears, the proposed distributed-flow-type planetary gear mechanism was operatively disposed between the rear sprocket and the hub shell for transmitting rotational power from the sprocket to the hub shell. Figs. 1(a) and 1(b), respectively, show a schematic diagram and the functional structure of the 13-link, distributed-flow-type planetary gear mechanism, which consists of two parallel-connected transmission units, namely Transmission units I and II, and one differential unit, namely Differential unit III. The input power from the rear sprocket splits into Transmission units I and II, and converges on Differential unit III to transmit the output power to the hub shell. A hub axle 0 is mounted on the bicycle frame. A rear sprocket supported by the hub axle receives the input power generated by the pedalling force. The hub shell is also supported by the hub axle to transmit the output power to the rear wheel. In the proposed distributed-flowtype planetary gear mechanism, as shown in Fig. 1(a), Transmission unit I is a basic planetary gear train, namely PGT I, consisting of a sun gear 1 , a ring gear $4_{R}$, a planet arm 5, a planet gear 9, a locking clutch Cf1 to lock sun gear 1 connecting to the stationary hub axle 0 and a pawland-ratchet clutch A to engage planet arm 5 with sun gear $4_{\mathrm{s}}$. Transmission unit II consists of two basic planetary gear trains, namely PGT II-1 and II-2, connected in series. This transmission unit contains sun gears 2 and 3, ring gears $6_{R}$ and $7_{R}$, planet gears 10 and 11 and planet arms 5 and $6_{C}$. Ring gear $6_{R}$ is combined with planet arm $6_{C}$ to be a single mechanical part. Two locking clutches $\mathrm{Cf} 2$ and $\mathrm{Cf3}$ are provided for sun gears 2 and 3, respectively. Two pawl-and-ratchet clutches $\mathrm{B}$ and $\mathrm{C}$ are installed to serial couple the planet arms of PGT II-1 and II-2. Differential unit III is also a basic planetary gear train, namely PGT III, consisting of a sun gear $4_{S}$, a planet arm $7_{C}$, a ring gear 8 and a planet gear 12. Sun gear $4_{S}$ is integrated with ring gear $4_{R}$ to be a compound gear, while ring gear $7_{R}$ is combined with planet arm $7_{\mathrm{C}}$ to form a single part. In addition, ring gear 8 is connected to the hub shell to output the rotational power. The DOF of this distributedflow-type planetary gear mechanism can be calculated by the Kutzbach's equation [12]:

$$
\begin{aligned}
& F=3(N-1)-2 J_{\mathrm{R}}-1 J_{\mathrm{G}}= \\
& =3(13-1)-2 \cdot 12-1 \cdot 8=4,
\end{aligned}
$$

where $F$ is the DOF of a mechanism, $N$ is the number of links, $J_{\mathrm{R}}$ is the number of revolute joints and $J_{\mathrm{G}}$ is the number of gear joints. In a 4-DOF gear mechanism, four constraints are needed to perform the constrained motion. One input constraint is planet arm 5's connection to the rear sprocket, thus three additional constraints are required to precisely control this distributed-flow-type planetary gear mechanism. This can be achieved by controlling the engagement of three clutches A or Cf1, B or $\mathrm{Ch} 2$ and $\mathrm{C}$ or $\mathrm{Cf} 3$ to dominate the power transmission paths of the internal gear hub.
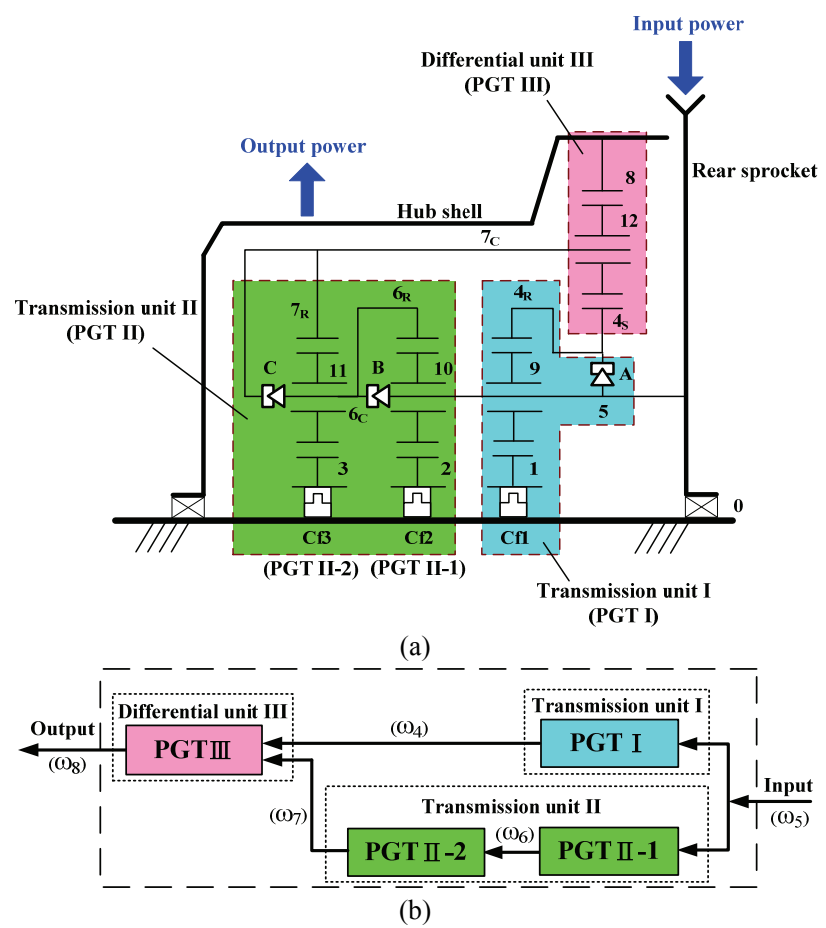

Figure 1 A schematic diagram and the functional structure of the proposed distributed-flow-type planetary gear mechanism: (a) Schematic diagram, (b) Functional structure

For the distributed-flow-type planetary gear mechanism shown in Fig. 1(a), there are eight fundamental circuits: $(1,9) 5,\left(4_{R}, 9\right) 5,(2,10) 5,\left(6_{R}, 10\right) 5$, $(3,11) 6_{C},\left(7_{R}, 11\right) 6_{C},\left(4_{S}, 12\right) 7_{C}$ and $(8,12) 7_{C}$; the corresponding fundamental circuit equations [13] are listed as: 
$\omega_{1}-\gamma_{9 / 1} \omega_{9}+\left(\gamma_{9 / 1}-1\right) \omega_{5}=0$

$\omega_{4 \mathrm{R}}-\gamma_{9 / 4 \mathrm{R}} \omega_{9}+\left(\gamma_{9 / 4 \mathrm{R}}-1\right) \omega_{5}=0$

$\omega_{2}-\gamma_{10 / 2} \omega_{10}+\left(\gamma_{10 / 2}-1\right) \omega_{5}=0$

$\omega_{6 \mathrm{R}}-\gamma_{10 / 6 \mathrm{R}} \omega_{10}+\left(\gamma_{10 / 6 \mathrm{R}}-1\right) \omega_{5}=0$

$\omega_{3}-\gamma_{11 / 3} \omega_{11}+\left(\gamma_{11 / 3}-1\right) \omega_{6 \mathrm{C}}=0$

$\omega_{7 \mathrm{R}}-\gamma_{11 / 7 \mathrm{R}} \omega_{11}+\left(\gamma_{11 / 7 \mathrm{R}}-1\right) \omega_{6 \mathrm{C}}=0$

$\omega_{4 \mathrm{~S}}-\gamma_{12 / 4 \mathrm{~S}} \omega_{12}+\left(\gamma_{12 / 4 \mathrm{~S}}-1\right) \omega_{7 \mathrm{C}}=0$

$\omega_{8}-\gamma_{12 / 8} \omega_{12}+\left(\gamma_{12 / 8}-1\right) \omega_{7 \mathrm{C}}=0$

where $\omega_{i}$ is the angular speed of link $i, \gamma_{j / i}= \pm Z_{j} / Z_{i}$ represents the gear ratio and $Z_{i}$ is the number of teeth on gear $i$. The positive sign of the gear ratio is for an internal gear joint, the negative for an external gear joint. By eliminating the angular speeds of planet gears, i.e., $\omega_{9}$, $\omega_{10}, \omega_{11}$ and $\omega_{12}$ from Eqs. (2) $\div$ (9), four kinematic equations of this gear mechanism are obtained as:

$$
\begin{aligned}
& \omega_{1}-K_{1} \omega_{4 \mathrm{R}}+\left(K_{1}-1\right) \omega_{5}=0 \\
& \omega_{2}-K_{2} \omega_{6 \mathrm{R}}+\left(K_{2}-1\right) \omega_{5}=0 \\
& \omega_{3}-K_{3} \omega_{7 \mathrm{R}}+\left(K_{3}-1\right) \omega_{6 \mathrm{C}}=0 \\
& \omega_{4 \mathrm{~S}}-K_{4} \omega_{8}+\left(K_{4}-1\right) \omega_{7 \mathrm{C}}=0
\end{aligned}
$$

where $K_{i}$ is denoted as the basic gear ratio, and $K_{1}=$ $-\mathrm{Z}_{4 \mathrm{R}} / \mathrm{Z}_{1}, K_{2}=-\mathrm{Z}_{6 \mathrm{R}} / \mathrm{Z}_{2}, K_{3}=-\mathrm{Z}_{7 \mathrm{R}} / \mathrm{Z}_{3}$ and $K_{4}=-\mathrm{Z}_{8} / \mathrm{Z}_{4 \mathrm{~S}}$, respectively. In such a transmission mechanism, the speed ratio (SR) is defined as the ratio of the input shaft speed to the output shaft speed. Different SRs are obtained by assigning the different sun gears 1, 2 or 3 as fixed links. This can be achieved by selectively controlling the engagement or disengagement of three locking clutches Cf1, Cf2 and Cf3. Therefore, a total of $C_{0}^{3}+C_{1}^{3}+C_{2}^{3}+C_{3}^{3}=8$ possible gears exist for the proposed distributed-flow-type planetary gear mechanism. Tab. 1 shows the $S R$ formula of each gear. By setting basic gear ratios as $K_{1}=-7 / 2, K_{2}=-5, K_{3}=-5 / 2$ and $K_{4}=-35 / 19$, the SR value of each gear can be calculated based on the derived SR formula. Tab. 2 shows the value of each SR and a corresponding clutching sequence table for the 8speed internal gear hub, where the symbol $\mathrm{X}$ indicates that the related clutch is activated for that gear. It is noted that three clutches are simultaneously activated for each gear to determine the power transmission path. A set of feasible solutions for the number of gear teeth so as to avoid gear interference are presented in Fig. 2. The proposed 8-speed internal gear hub with a total gear ratio of up to $242,6 \%$ is achieved, and it provides eight forward gears, including a low-speed gear G-1, a direct gear G-2 and six high-speed gears G-3 to G-8. For the forward gear G-1 shown in Fig. 3(a), a locking clutch Cf1 and two pawl-and-ratchet clutches $\mathrm{B}$ and $\mathrm{C}$ are engaged. An important feature of this planetary gear mechanism is that pawl-and-ratchet clutches $\mathrm{A}, \mathrm{B}$ and $\mathrm{C}$ are automatically engaged based on the activation of locking clutches Cf1, Cf2 and Cf3. Because locking clutches Cf2 and Cf3 are not activated for forward gear G-1, the power from planet arm 5 is directly transmitted via planet arm $6_{C}$ to planet arm $7 \mathrm{C}$. Therefore, pawl-and-ratchet clutches $\mathrm{B}$ and $\mathrm{C}$ are automatically engaged. In such a manner, PGT II- 1 and II-2 are integrated into a single part and idle rotation. The power from the rear sprocket is transmitted into planet arm 5 and then splits into two power transmission paths via planet gear 9 and Transmission unit II, respectively. One power transmission path is from planet gear 9 via ring gear $4_{R}$ of Transmission unit I to sun gear $4_{\mathrm{s}}$. The other power transmission path is from Transmission unit II directly to planet arm $7_{\mathrm{C}}$, because the whole Transmission unit II is idle rotating. These two power transmission paths converge on Differential unit III, while the output power is finally transmitted to the hub shell via ring gear 8 , as shown in Fig. 3(a). Power transmission paths for gears G-2 to G- 8 are presented in Figs. 3(b) to 3(h), respectively.

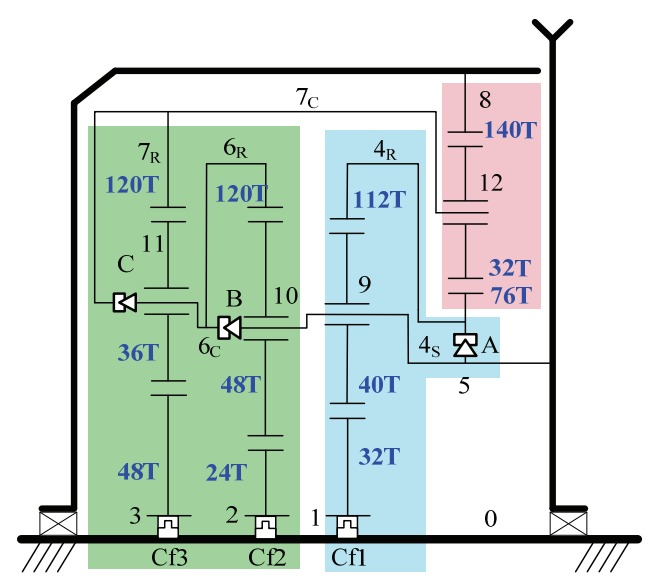

Figure 2 The number of gear teeth of the 8-speed internal gear hub

Table $1 S R$ formula of each speed of the internal gear hub

\begin{tabular}{|c|c|}
\hline \begin{tabular}{c} 
Fixed link / $\begin{array}{c}\text { Input link } \\
\text { Output link }\end{array}$ \\
\hline- - $5 / 8$
\end{tabular} & $S R$ formula \\
\hline $1 / 5 / 8$ & $S R_{1}=\frac{K_{1} K_{4}}{K_{1} K_{4}-1}$ \\
\hline $2 / 5 / 8$ & $S R_{2}=\frac{K_{4} K_{2}}{\left(K_{4} K_{2}-K_{4}\right)+1}$ \\
\hline $3 / 5 / 8$ & $S R_{3}=\frac{K_{4} K_{3}}{\left(K_{4} K_{3}-K_{4}\right)+1}$ \\
\hline $1 \& 2 / 5 / 8$ & $S R_{1 \& 2}=\frac{1}{\frac{K_{1}-1}{K_{1} K_{4}}+\frac{\left(K_{2}-1\right)\left(K_{4}-1\right)}{K_{2} K_{4}}}$ \\
\hline $1 \& 3 / 5 / 8$ & $S R_{1 \& 3}=\frac{1}{\frac{K_{1}-1}{K_{1} K_{4}}+\frac{\left(K_{3}-1\right)\left(K_{4}-1\right)}{K_{3} K_{4}}}$ \\
\hline $2 \& 3 / 5 / 8$ & $S R_{2 \& 3}=\frac{1}{\frac{1}{K_{4}}+\frac{\left(K_{2}-1\right)\left(K_{3}-1\right)\left(K_{4}-1\right)}{K_{2} K_{3} K_{4}}}$ \\
\hline $1 \& 2 \& 3 / 5 / 8$ & $\frac{K_{1}-1}{K_{1} K_{4}}+\frac{\left(K_{2}-1\right)\left(K_{3}-1\right)\left(K_{4}-1\right)}{K_{2} K_{3} K_{4}}$ \\
\hline & $S$ \\
\hline
\end{tabular}




\section{Embodiment design of a rotary gear-shifting control mechanism}

A gear-shifting control mechanism is a mechanical device within an internal gear hub which operates with the planetary gear mechanism and selectively controls the engagement or disengagement of each clutch, according to the clutching sequence table, so as to provide a set of power transmission paths. For a multi-speed internal gear hub, a rotary type gear-shifting control mechanism is more suitable than an axially moveable type due to the limited available space in the axial direction of a bicycle's internal gear hub. A simple rotary gear-shifting control mechanism disposed on a stationary hub axle is illustrated in Fig. 4. This mechanism includes a control sleeve, a control link and an annular control plate supported by the hub axle. The control sleeve is a rotary indexing part manipulated by the cyclist through a lever-actuated shifting device installed on the bicycle's handlebar. The control sleeve rotates synchronously with the annular control plate due to the engagement of keys on the annular control plate and slots on the control sleeve. The annular control plate is concentrically surrounded by the control sleeve. The inner peripheral surface of the annular control plate is configured with several retaining slots for engagement with the control link, as shown in Fig. 5(a). A sun gear is also provided on the inner edge with a toothed ratchet wheel that contains a plurality of retaining slots for engagement with the control link, as shown in Fig. 5(b). A spring-held control link, which is installed in the slot area of the stationary hub axle by pins, is configured with pawls $\mathrm{A}$ and $\mathrm{B}$ at two ends to engage with the retaining slots of the sun gear and the annular control plate, respectively. Pawl A and the toothed ratchet wheel on the inner edge of the sun gear form a one-way locking clutch to determine the rotational movement of the sun gear. Once the spring-held pawl B of the control link is activated, pawl A is forced to engage with the retaining slot of the sun gear. In such a situation, the locking clutch is engaged, and the sun gear couples to the stationary hub axle as a fixed link.

Table 2 The value of each SR and the corresponding clutching sequence table of the 8-speed internal gear hub

\begin{tabular}{|c|c|c|c|c|c|c|c|}
\hline \multirow{2}{*}{ Gear } & \multirow{2}{*}{ SR value } & \multicolumn{5}{|c|}{$\begin{array}{c}\text { Clutching sequence table } \\
\text { clutches }\end{array}$} \\
\cline { 3 - 8 } & & $\mathrm{A}$ & $\mathrm{B}$ & $\mathrm{C}$ & $\mathrm{Cf1}$ & $\mathrm{Cf2}$ & $\mathrm{Cf3}$ \\
\hline & 1,184 & & $\mathrm{X}$ & $\mathrm{X}$ & $\mathrm{X}$ & & \\
\hline G-1 & 1,000 & $\mathrm{X}$ & $\mathrm{X}$ & $\mathrm{X}$ & & & \\
\hline G-2 & 0,867 & & & $\mathrm{X}$ & $\mathrm{X}$ & $\mathrm{X}$ & \\
\hline G-3 & 0,764 & $\mathrm{X}$ & & $\mathrm{X}$ & & $\mathrm{X}$ & \\
\hline G-4 & 0,684 & & $\mathrm{X}$ & & $\mathrm{X}$ & & $\mathrm{X}$ \\
\hline $\mathrm{G}-5$ & 0,618 & $\mathrm{X}$ & $\mathrm{X}$ & & & & $\mathrm{X}$ \\
\hline $\mathrm{G}-6$ & 0,528 & & & & $\mathrm{X}$ & $\mathrm{X}$ & $\mathrm{X}$ \\
\hline $\mathrm{G}-7$ & 0,488 & $\mathrm{X}$ & & & & $\mathrm{X}$ & $\mathrm{X}$ \\
\hline G-8 & & & & & & & \\
\hline
\end{tabular}

The pawl-and-ratchet clutches $\mathrm{A}, \mathrm{B}$ and $\mathrm{C}$ are automatically controlled by the angular speeds of the pawl element and the ratchet element. Once the angular speed of the pawl element is larger than that of the ratchet element, the pawl-and-ratchet clutch is engaged. Otherwise, the pawl-and-ratchet clutch is un-engaged. Therefore, pawl-and-ratchet clutches $\mathrm{A}, \mathrm{B}$ and $\mathrm{C}$ are automatically engaged at each gear stage, only locking clutches $\mathrm{Cf1}$, Cf2 and Cf3 need to be manually controlled by a rotary gear-shifting control mechanism.

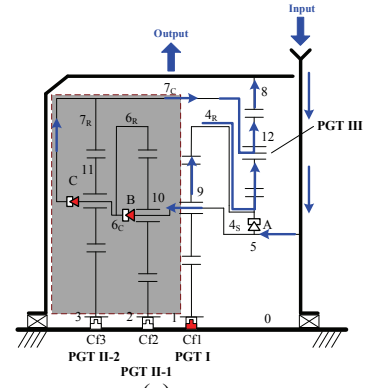

(a)

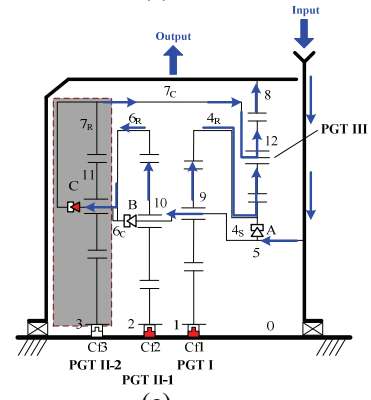

(c)

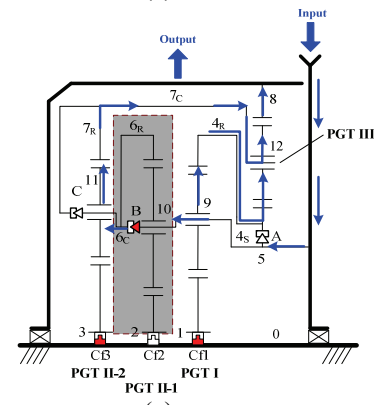

(e)

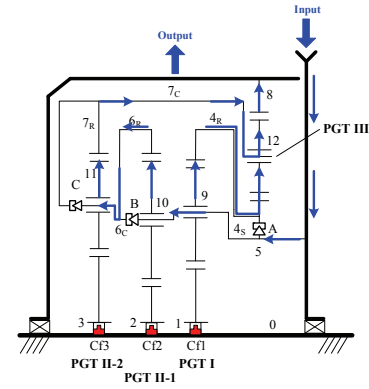

(g)

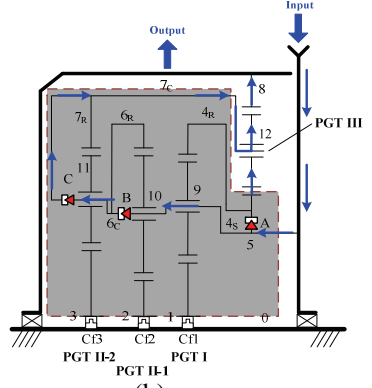

(b)

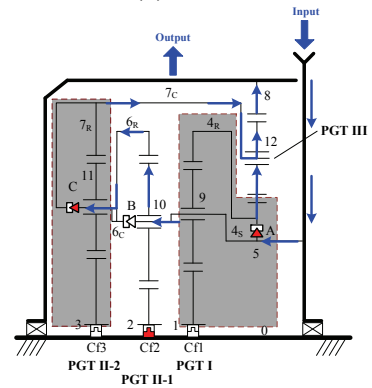

(d)

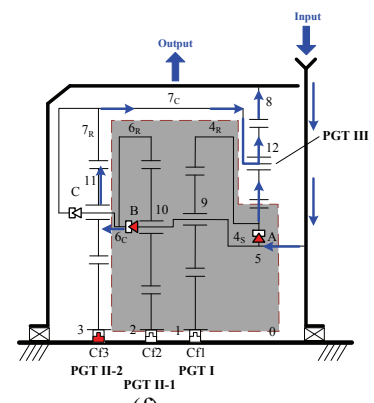

(f)

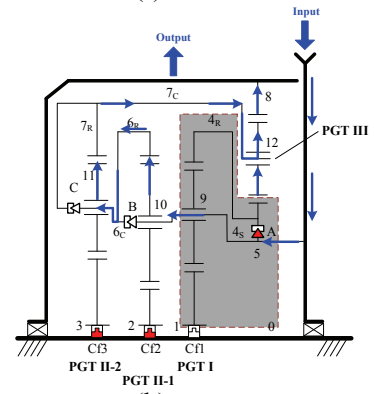

(h)
Figure 3 Power transmission path of each gear of the 8-speed internal gear hub: (a) forward gear G-1, (b) forward gear G-2, (c) forward gear G-3, (d) forward gear G-4, (e) forward gear G-5, (f) forward gear G-6, (g) forward gear G-7, (h) forward gear G-8

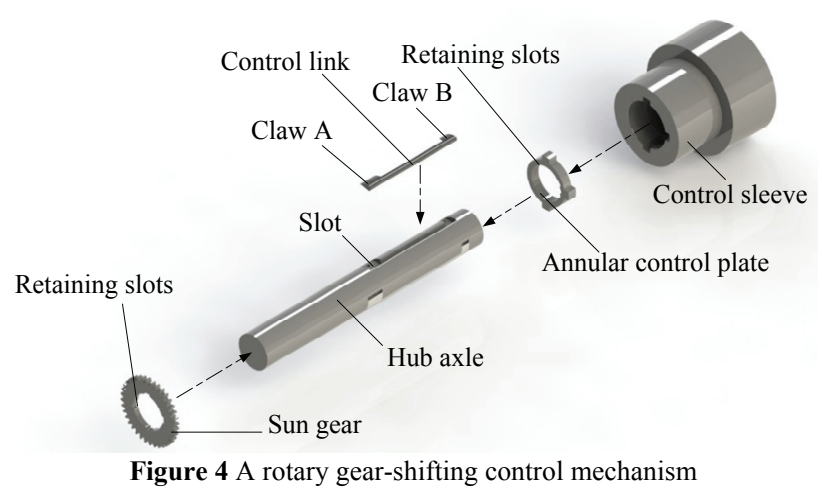




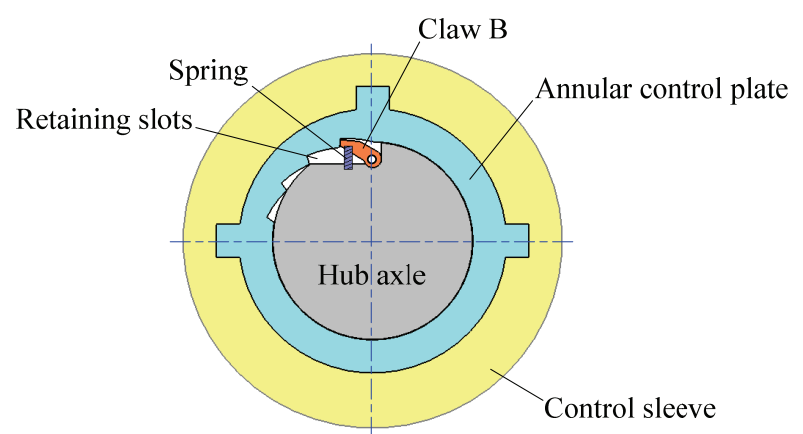

(a)

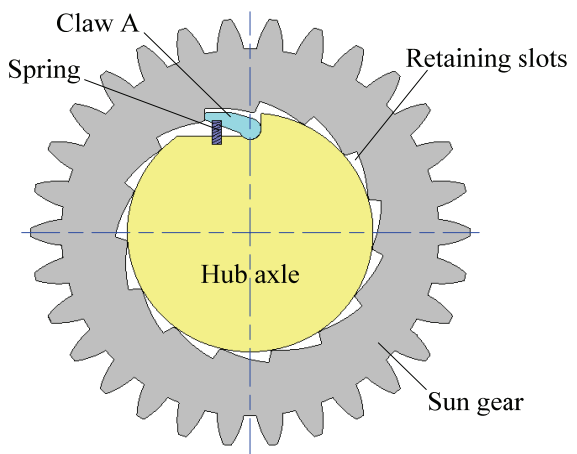

(b)

Figure 5 Cross sectional views of a rotary gear-shifting control mechanism

For Transmission units I and II of the proposed planetary gear mechanism shown in Fig. 2, three independent sun gears 1,2 and 3 are controlled by the activation of locking clutches $\mathrm{Cf} 1, \mathrm{Cf} 2$ and $\mathrm{Cf} 3$, respectively. Therefore, three annular control plates associated with the three control links and one control sleeve are required in the design of a rotary gear-shifting control mechanism for an 8-speed internal gear hub. Retaining slots on the inner peripheral surface of an annular control plate are key components which govern the activation of a locking clutch, and which can be designed with the aid of an annular schematic diagram. The proposed internal gear hub is configured to provide 8 forward gears; thus, the annular schematic diagram is circularly divided into 8 parts. Each arc-shaped area is sequentially denoted as G-1 to G-8 in a clockwise direction. The configuration design of an annular control plate for locking clutch $\mathrm{Cf} 1$ has been used as an example. According to the clutching sequence table shown in Tab. 2, locking clutch $\mathrm{Cf1}$ is engaged at gears G-1, G-3, G-5 and G-7. The corresponding arc-shaped areas of the annular schematic diagram for gears G-1, G-3, G-5 and G-7 are marked with a dark colour, as shown in Fig. 6(a). The inner peripheral surface of the annular control plate is correspondingly configured with retaining slots for those gears with a dark colour to meet the engagement function of the locking clutch $\mathrm{Cf1}$, as shown in Fig. 7(a). In the same manner, the annular schematic diagram for locking clutches Cf2 and Cf3 is plotted in Figs. 6(b) and 6(c), respectively. The configuration design of the annular control plates for locking clutches $\mathrm{Cf} 2$ and $\mathrm{Cf} 3$ is illustrated in Figs. 7(b) and 7(c), respectively. Because the three control links must be assembled into related slot areas on the stationary hub axle, the control links for locking clutches $\mathrm{Cf} 1, \mathrm{Cf} 2$ and $\mathrm{Cf} 3$ are arranged clockwise at equal circular intervals to prevent interference, as shown in Figs. 8(a) and 8(b). The orientation of each annular control plate is further modified according to the relative position of each control link installed on the hub axle. Figs. 9(a), 9(b) and 9(c) illustrate the relative orientation of the annular control plates disposed on the stationary hub axle for locking clutches Cf1, Cf2 and Cf3, respectively. The exploded view of the completed rotary gear-shifting control mechanism for the proposed 8-speed internal gear hub is presented in Fig. 10.

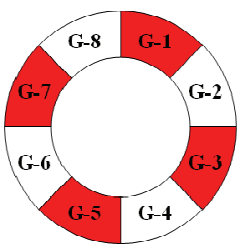

(a)

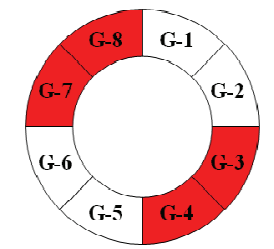

(b)

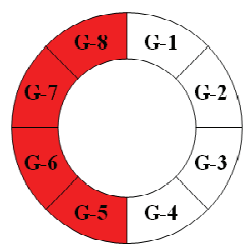

(c)
Figure 6 Annular schematic diagrams of annular control plates for locking clutches: (a) Cf1, (b) $\mathrm{Cf} 2$ and (c) Cf3

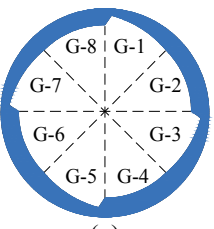

(a)

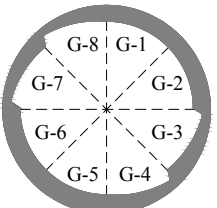

(b)

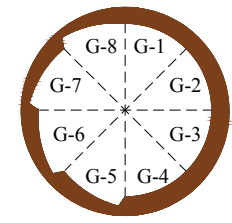

(c)
Figure 7 Configuration design of annular control plates for locking clutches: (a) Cf1, (b) Cf2 and (c) Cf3

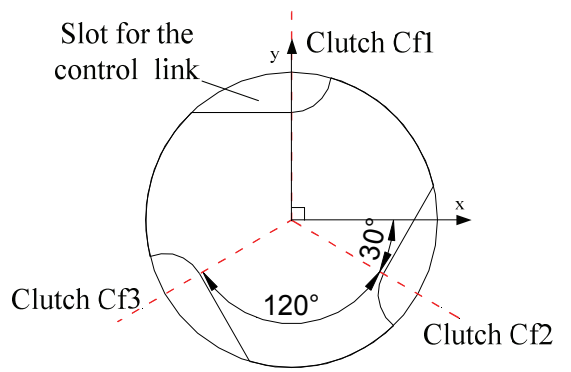

(a)

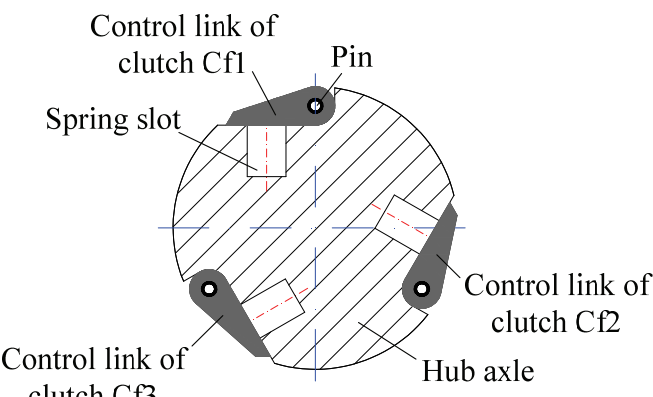

(b)

Figure 8 Three locking clutches Cf1, Cf2 and Cf3 are arranged clockwise at equal circular intervals to prevent interference

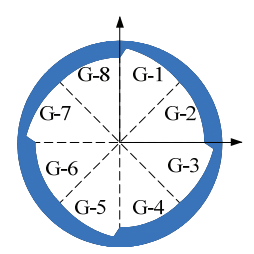

(a)

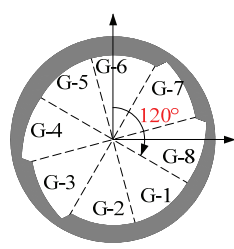

(b)

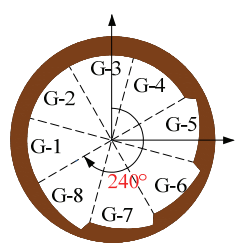

(c)
Figure 9 Relative orientation of annular control plates disposed on the stationary hub axle for locking clutches: (a) Cf1, (b) Cf2 and (c) Cf3 


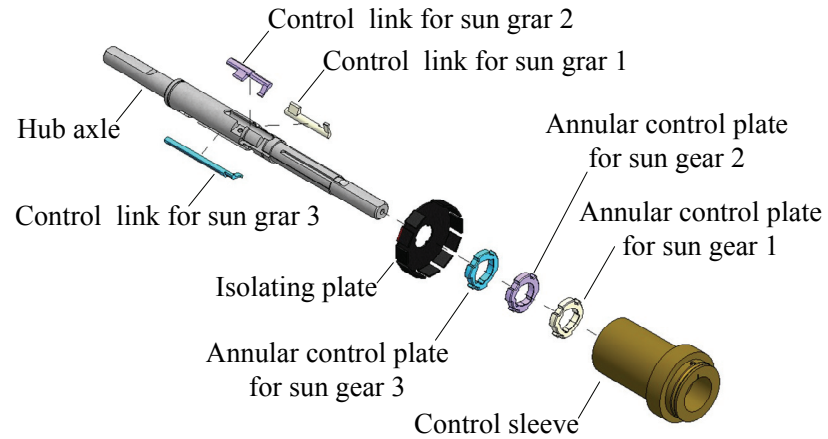

Figure 10 Exploded view of the rotary gear-shifting control mechanism

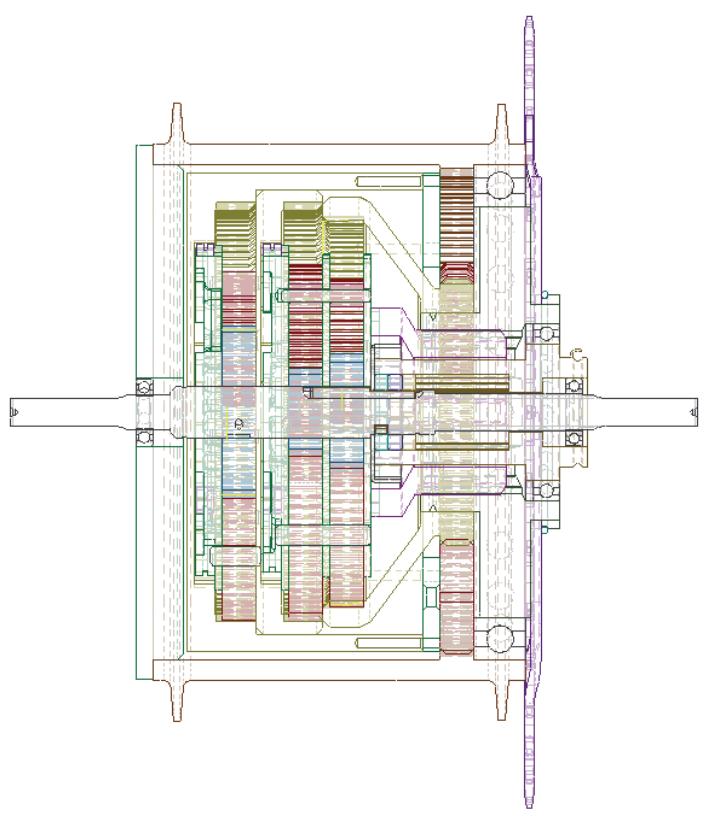

(a)

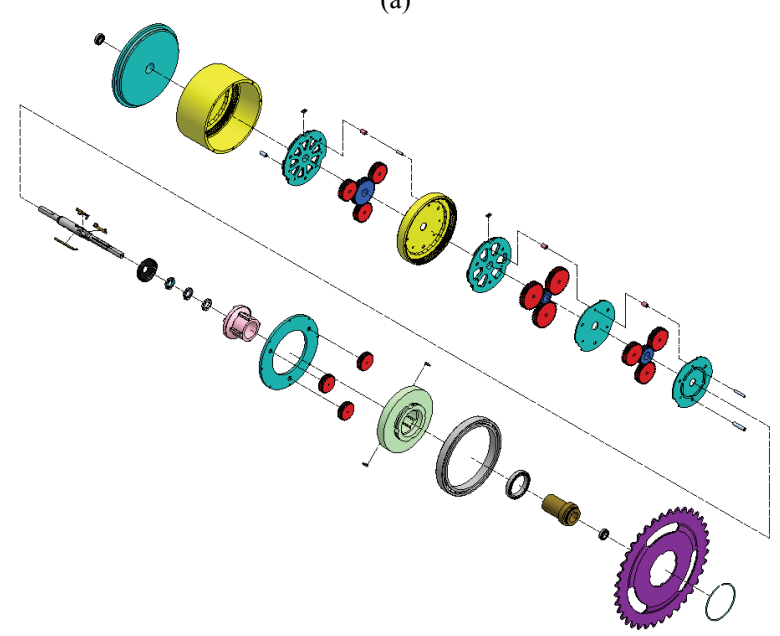

(b)

Figure 11 The proposed 8-speed internal gear hub for bicycles: (a) Assembly drawing, (b) Exploded drawing

\section{A novel 8-speed internal gear hub for bicycles}

By integrating the rotary gear-shifting control mechanism within the distributed-flow-type planetary gear mechanism disposed on a stationary hub axle, a novel 8-speed internal gear hub for bicycles was designed. Fig. 11(a) shows the perspective front view of the assembly drawing of the presented embodiment while Fig. 11(b) illustrates the exploded view of the 8-speed internal gear hub. In contrast to existing 8-speed internal gear hubs in the current market, our proposed design has the following features:

(1) The distributed-flow-type planetary gear mechanism possesses a wide total gear ratio of up to $242,6 \%$. It provides a low-speed gear, a direct gear and six highspeed gears, and thus is more suitable for city bikes.

(2) The rotary gear-shifting control mechanism is designed with a relatively simple and compact structure. It is operated according to the clutching sequence table to carry out a power source impartation.

(3) Three pawl-and-ratchet clutches A, B and C are automatically engaged at each gear stage based on the activation of locking clutches $\mathrm{Cf} 1, \mathrm{Cf} 2$ and $\mathrm{Cf} 3$. So, it is not necessary to manually control the engagement/disengagement of pawl-and-ratchet clutches, which greatly simplifies the mechanical components as well as the structural complexity of the rotary gear-shifting control mechanism.

\section{Conclusion}

A bicycle's internal gear hub is a multi-speed transmission device; it is compact, durable, reliable and highly efficient. This paper has presented the embodiment design of a novel 8-speed internal gear hub for bicycles. A 13-link, 4-DOF distributed-flow-type planetary gear mechanism was employed as the main body of the internal gear hub to provide 8 forward speeds. A feasible and compact rotary gear-shifting control mechanism was designed to operate together with the planetary gear mechanism and govern the power transmission path at each gear stage. Future work on this subject would include a detailed design of the embodiment to elaborate on the current detailed drawings and parts' lists and the development of a prototype to verify the validity of the proposed 8-speed internal gear hub.

\section{Acknowledgement}

Financial support from National Science Council project (Taiwan, R.O.C.) NSC 102-2221-E-224-016-MY2 is appreciated.

\section{References}

[1] Schulz, H.; Schwerdhofer, H. Multiple speed hub with coaster brake. // U.S. patent No. 3, 809, 195 (1974).

[2] Hillyer, A. W. Epicyclic chang speed hubs. // U.S. patent No. 3, 886, 811 (1975).

[3] Uchiyama, Y. Internal bicycle hub transmission having an operating unit disposed inboard of the free end of an axle. // U.S. patent No. 6, 134, 980 (2000).

[4] Steuer, W. Drive hub for bicycles or the like. // U.S. patent No. 4, 400, 999 (1983).

[5] Su, H. Y.; Chen, H. C. Fixed gear internal gear hub. // U.S. patent No. 8, 388, 490 (2013).

[6] Munn, D. C. Epicyclic change-speed hubs. // U.S. patent No. 3, 955, 444 (1983).

[7] Meier-Burkamp, G. Multi-speed hub for bicycles. // U.S. patent No. 5, 527, 230 (1996).

[8] Hsu, C. H.; Wen, T. C. Creative Design Methodology for Split-Power Multi-Speed Drive Hubs of Bicycles (in Chinese). // Proceedings of the 11th National Conference 
on the Design of Mechanisms and Machines / Hsinchu, Taiwan, 2008, Paper No. A1N-51943.

[9] Wu, Y. C.; Ren, P. W. Design and Analysis of a Multispeed Transmission Hub. // INFORMATION - An International Interdisciplinary Journal. 16, 9B(2013), pp. 7003-7014.

[10] Hsieh, W. H. Kinetostatic and Mechanical Efficiency Studies on Cam-Controlled Planetary Gear Trains-Part I Theoretical Analysis. // Indian Journal of Engineering and Materials Sciences. 20, 3(2013), pp. 191-198.

[11] Hsieh, W. H. Kinetostatic and Mechanical efficiency Studies on Cam-Controlled Planetary Gear Trains-Part II Design and Experiment. // Indian Journal of Engineering and Materials Sciences. 20, 3(2013), pp. 199-204.

[12] Norton, R. L. Kinematics and Dynamics of Machinery. 1st ed. McGraw-Hill Company, Singapore, 2009

[13] Tsai, L. W. Mechanism Design: Enumeration of Kinematic Structures According to Function. CRC Press LLC, Florida, 2001

\section{Authors' addresses}

Yi-Chang Wu, Associate Professor Ph.D

Department of Mechanical Engineering

National Yunlin University of Science \& Technology

123, Sec. 3. University Rd, Douliou, Yunlin, Taiwan 640, R.O.C

E-mail:wuyc@yuntech.edu.tw

\section{Li-An Chen, Graduate Student}

Department of Mechanical Engineering

National Yunlin University of Science \& Technology

123, Sec. 3. University Rd, Douliou, Yunlin, Taiwan 640, R.O.C.

E-mail: ycwu062@hotmail.com 